\title{
A Comparison of the Seasonal Influenza Vaccination Rates and Related Factors
}

\author{
Mevsimsel Grip Aşılama Oranı ve ilişkkili Faktörlerin Karşılaştııılması
๑ Melike Mercan Başpınar, ๑ Ezgi Tanımlı, ๑ Sıddıka Gedik Depreli, ๑ Hilal Kale Aktaş, ๑ Recep Aktaş, ๑ Okcan Basat

University of Health Sciences Turkey, Gaziosmanpaşa Training and Research Hospital, Department of Family Practice, Istanbul, Turkey

\section{Abstract}

Aim: This study aimed to evaluate the effect of vaccine recommendations on vaccine uptake, patients' attitudes, influenza vaccination rates, and flu-like illness in the previous year.

Methods: A cross-sectional study was designed with patients (aged $\geq 18$ years) who attended family medicine-vaccine clinics at a tertiary hospital between November 2019 and January 2020.

Results: The influenza vaccination rate among 391 patients (mean age: $39.9 \pm 13.5$ years) was $22.5 \%$ (88/391), and the rate of participants who were recommended to receive the vaccine was $25.3 \%$ of all with a moderate agreement (Kappa $=0.39$ $\mathrm{p}<0.001)$, although $81.3 \%$ of the subjects believed that the vaccine was beneficial and half of the patients (50.5\%) positively reacted when their physician recommended. Seventeen point nine of patients who had flu-like illnesses in the previous year $(72.6 \%)$ had been vaccinated. Experienced side-effect, fear of side effects and injection, and vaccine hesitancy were not barriers to vaccination acceptance. The presence of recommendation [ $p<0.001$; Odds ratio (OR): 5.35; 95\% confidence interval $(\mathrm{Cl})$ : 2.92-9.78], information on timing of vaccination ( $p=0.001$; OR: $4.18 ; 95 \% \mathrm{Cl}: 1.82-9.59)$, and belief about benefits of vaccine ( $p=0.01$; OR: $5.42 ; 95 \% \mathrm{Cl}: 1.40-21.03$ ) were the predictors of vaccine acceptance.

Conclusion: This study would contribute to a strategy, including (i) doctors' vaccine recommendation, (ii) patient's belief of benefit (iii) vaccination schedule (month) information, to increase the rates of influenza vaccination.

Keywords: Family medicine, influenza, vaccine reccomendation, vaccination
Öz

Amaç: Bu çalışma, aşı önerilerinin aşı alımı, hastaların tutumları, grip aşılama oranları ve geçen yıl grip benzeri hastalık üzerindeki etkilerini değerlendirmeyi amaçlamıştır.

Yöntemler: Kasım 2019 - Ocak 2020 tarihleri arasında üçüncü basamak bir hastanenin aile hekimliği-aşı kliniklerine başvuran hastalar ( $\geq 18$ yaş) ile kesitsel bir çalışma tasarlanmıştır.

Bulgular: Her ne kadar çalışma popülasyonunun \%81,3'ü aşılamanın faydalı olduğuna inansa ve hastaların yarısı $(\% 50,5)$ doktorları aşı önerdiğinde öneriye uymuş olsa bile, 391 hastanın (ortalama yaş:39,9, standart sapma=13,5) aşı yaptırma oranı $\% 22,5$ (88/391), önerilme oranı \%25,3 olup birbirleri ile orta derece uyumlu (Kappa=0,39 p<0,001) idi. Geçen yıl grip benzeri hastalık geçirenlerin $(\% 72,6)$ \%17,9'luk kısmı aşılanmıştır. Yan etki deneyimi, yan etki korkusu, enjeksiyon kaygısı ve aşı karşıtlığı aşı olmayı kabul etmeye engel bir durum değildi. Öneri varlığı ( $p<0,001$; Odds oranı (OR): 5,35; \%95 güven aralığı $(\mathrm{Cl}):$ 2,929,78), aşılanma zaman bilgisi ( $p=0,001$; OR: 4,18; \%95 Cl: 1,82$9,59)$ ve aşı fayda inancı ( $p=0,01$; OR: 5,$42 ; \% 95 \mathrm{Cl}: 1,40-21,03)$, aşılanmada belirleyici faktörlerdi.

Sonuç: Bu çalışma grip aşısı oranlarını arttırmaya yönelik, (i) doktor tavsiyesi, (ii) hastanın fayda inancı ve (iii) aşı zaman (ay) bilgisini içerecek bir strateji oluşumuna katkıda bulunacaktır.

Anahtar Sözcükler: Aile hekimliği, influenza, aşı önerisi, aşılama

\footnotetext{
Address for Correspondence/Yazışma Adresi: Melike Mercan Başpınar, University of Health Sciences Turkey, Gaziosmanpaşa Training and Research Hospital, Department of Family Practice, İstanbul, Turkey

E-mail: drmelikemercan@gmail.com ORCID: orcid.org/0000-0003-3183-3438

Received/Geliş Tarihi: 04 February 2020 Accepted/Kabul Tarihi: 01 March 2020

The Turkish abstract of this study was accepted as an oral presentation in "9th. International Trakya Family Medicine Congress-March 2020, Edirne, Turkey" $7^{\text {th }}$ March 2020 by Okcan Basat.
}

${ }^{-}$Copyright 2020 by The Medical Bulletin of istanbul Haseki Training and Research Hospital The Medical Bulletin of Haseki published by Galenos Yayınevi. OTelif Hakkı 2020 istanbul Haseki Eğitim ve Araştırma Hastanesi Haseki Tıp Bülteni, Galenos Yayınevi tarafından yayınlanmıştır. 


\section{Introduction}

After the discovery of vaccines and antibiotics, we declared heroes against diseases, but recently, we have global discussions about antibiotic drug resistance and vaccine hesitancy as public health problems. From the history of influenza epidemics and pandemics for the past three hundred years, it is apparent that outbreaks occur somewhere in the world in most years (1). Although the most effective and economical method of protecting health is still vaccination, the general acceptance of the H1N1 influenza vaccination has been low worldwide. The potential health risks of the novel influenza A (H1N1) strain, distrust in vaccines, and concerns about vaccine safety are the main reasons reported by the public for not undergoing vaccination (2). Ebola and several other hemorrhagic fevers, including Zika, Nipah, Middle East respiratory syndrome coronavirus, severe acute respiratory syndrome, disease $X$, and dengue, that could cause serious epidemics have not yet been health threats for Turkey. This list is an indication of changing health challenges, and that non-communicable diseases and environmental threats pose just as great a risk for the future (3).

The Advisory Committee on Immunization Practices - the US Centers for Disease Control and Prevention recommended routine influenza vaccination for all people who do not have contraindications from 2010 and updated the recommendation in 2019 (4). World Health Organisation (WHO) redefined the priority groups in 2012 . In our country, based on the WHO recommendations, vaccination is provided free of charge for individuals and healthcare professionals who are identified as priority group. Patient groups with high risk of influenza-related complications are children ( $<5$ years), elderly ( $\geq 65$ years), pregnant women, nursing home residents, patients with chronic diseases (asthma, cerebral palsy, epilepsy, mental retardation, heart failure, HIV/AIDS, cancer, chronic steroid use, rheumatic disease treatment, biological agent use, obesity (BMI $>40 \mathrm{~kg} / \mathrm{m}^{2}$ ), chronic kidney disease, chronic liver diseases, etc). There are triple (trivalent) and quadruple (tetravalent, quadrivalent) inactive vaccines in our country as of the 2018-2019 season. The protective effect of the vaccine begins 1-2 weeks after administration. Therefore, the best time to get vaccinated is just before the months when flu is most common (October and November), but vaccination can be done at any time during the influenza season (5).

There are studies indicating the importance of vaccination recommendations. Many studies have shown that the annual cost of vaccine-preventable diseases in the US is $\$ 9-26$ million, while $80 \%$ ( $\$ 7.1$ million) of this amount is spent for the treatment of non-vaccinated people. At the same time, it has been shown that influenza made up $\$ 16.0$ billion (60\%) of the cost among adults 50 and older $(6,7)$.

In order to reach the desired target in vaccination, it is essential to know the deficiencies in the vaccination program and create awareness. We hypothesized that there is a strong relationship between the vaccination rate and the presence of recommendations. We aimed (i) to assess the influenza vaccine attitudes, beliefs, the status of last year flu attack, and the effectiveness of the previous vaccination in flu or acute respiratory diseases (ii) to identify predictors of patients' vaccine receipt.

\section{Methods}

All data were collected from 391 patients who applied to the family medicine-vaccine clinics at a tertiary hospital between November 2019 and January 2020. Only volunteers (aged $>18$ years old) were included in this study. The patients were asked the following questions: "Have you ever been offered an influenza vaccination by a health professional at any visit? Did you have a flu-like illness last year? Have you had a influenza vaccine in the previous flu season? "A cross-sectional study was designed by a faceto-face survey, including socio-demographic data, chronic diseases, vaccination status, knowledge, and beliefs about influenza vaccination.

The patients were informed about the survey and verbal consent was obtained from participants at the time of questionnaire distribution. Only volunteers were included in the study. The privacy of the data was completely protected and used only for research purposes. The Local Ethics Committee of Taksim Training and Research Hospital Clinical Research reviewed and approved this study on date 11/12/2019 (approval no:170). All authors read and carried out the principles of the Helsinki Declaration. This article does not contain any studies with animals performed by any of the authors.

\section{Statistical Analysis}

Data were analyzed with the NCSS 10 (2015 Kaysville, USA) program. Descriptive statistics were used to measure the frequency, mean, and standard deviation of variables. The chi-square test results summarized categorical data comparisons. The logistic regression test analyzed clinically significant variables. A $p$ value of $<0.05$ was considered statistically significant.

\section{Results}

A total of 391 patients, including 202 (51.7\%) female and $189(48.3 \%)$ male individuals, completed the study for two months. The average age was $39.9 \pm 13.5$ years. In terms of educational level, 92 participants (49.1\%) had completed eight-year basic education, and 199 (50.9\%) had a high school and/or university education. More 
than half of the participants were working (62.9\%). Most participants had not been vaccinated against seasonal influenza (77.5\%) in the previous year. Although $25.3 \%$ (99/391) of participants reported that they had been recommended to receive the seasonal influenza vaccine, the vaccination rate was $22.5 \%(88 / 391)$ of all. The mean age of the adults vaccinated was $42.3 \pm 14.7$ years. Table 1 shows the assessment of sociodemographic variables according to vaccination and previous recommendation status.

Thirty-six percent of patients over 65 years of age (9/25 patients) received a flu vaccine, but there was no difference in vaccination rate between the age groups. Twenty-four percent of patients younger than 65 years old (88/366 patients) were offered influenza vaccine, while $44 \%$ of patients over 65 years old (11/25 patients) were recommended. There was a significant difference in the presence of recommendation between those aged $<65$ years group and $>65$ years $(p=0.04)$, despite vaccination rates were similar. The rate of vaccination and recommendation was higher in employed individuals than in non-workers (housewife, unemployed, retired, etc.) ( $p=0.01$ and $p=0.005$, respectively). There was no significant difference in gender, marital status, educational background, and presence of any chronic disease between vaccinated and unvaccinated groups ( $p>0.05$ ). Participants reported that they were recommended to receive influenza vaccine mostly by physicians (89\%), television (7.2\%), pharmacists $(2.3 \%)$, and the internet $(1.5 \%)$, respectively. Figure 1 shows that the most significant source of the information was physicians in the recommendation and vaccination groups. There was a moderate agreement between recommendation and vaccination (Kappa $=0.39 \mathrm{p}<0.001)$. Fifty point five percent of those, who were recommended, were vaccinated. Even though the patients were mostly informed by a physician $(92.9 \%$ in the recommended group; $92 \%$ in vaccinated

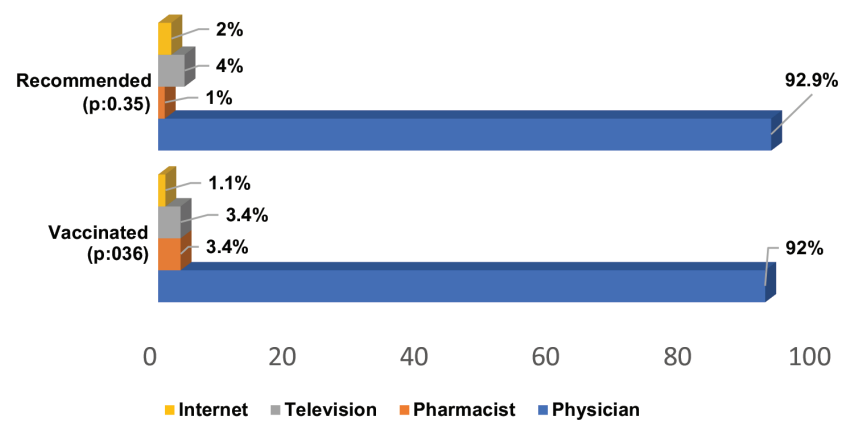

Figure 1. Evaluation of the recommendation and vaccination groups according to the distribution of information sources

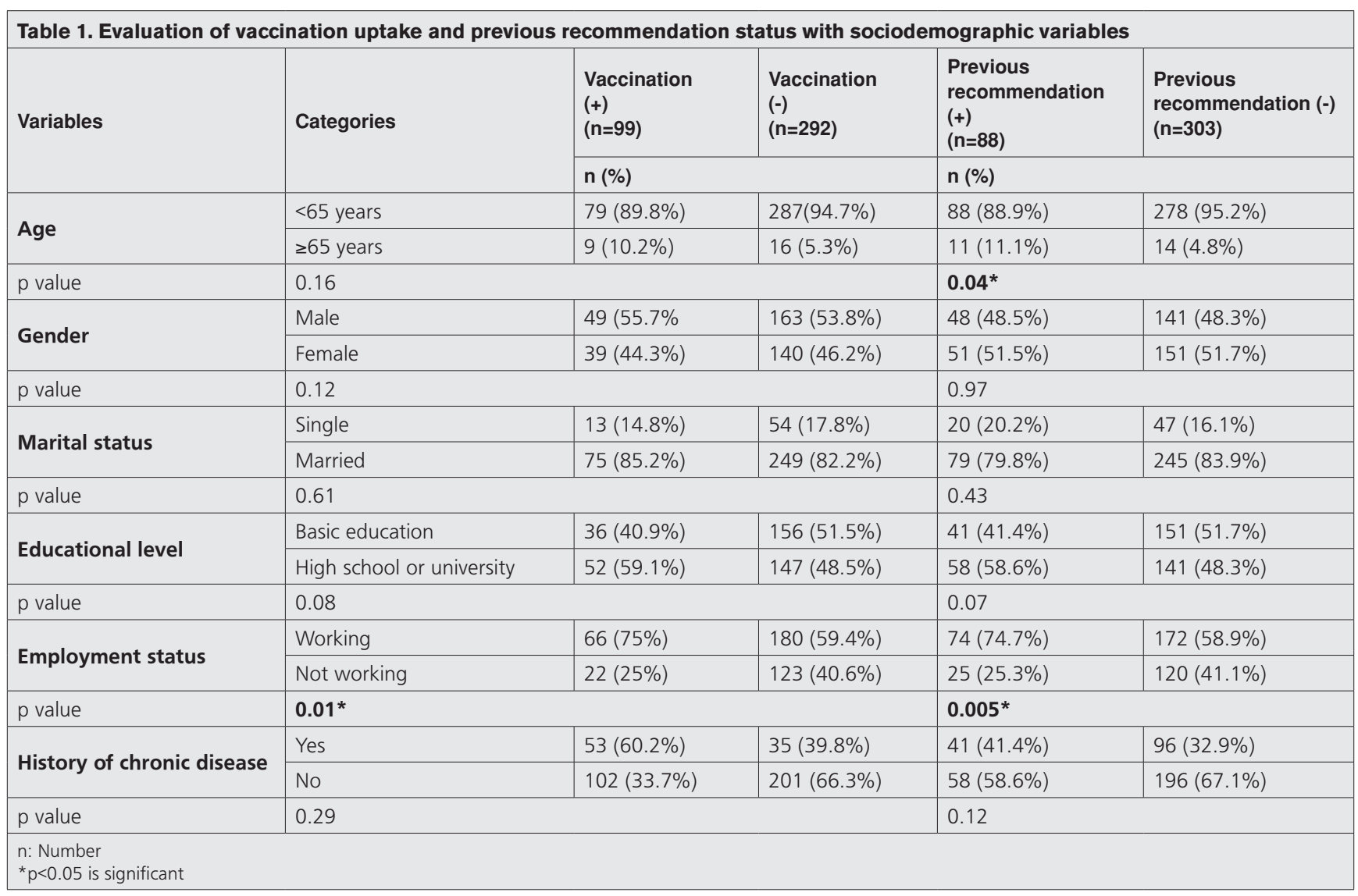


patients), a significant difference was not indicated between the vaccination $(+)(-) /$ recommendation $(+)(-)$ groups in distribution (physicians, television, pharmacists and the internet) of the information source groups ( $p$ Recommendation presence-Knowledge source $=0.35$; p paccination uptakeKnowledge source $=0.36$ ).

One hundred and thirty seven participants (35\%) had a chronic disease. Sixty-four patients (16.4\%) - asthma/ chronic obstructive disease (COPD), 44 patients (11.3\%) chronic cardiovascular disease (CVD), 42 patients (10.7\%) - Diabetes Mellitus (DM), and 19 patients (4.9\%) had immunosuppression (HIV/AIDS, cancer, cancer treatment, chronic steroid use, anti-rheumatic treatment, etc.). In Figure 2, the distribution of the disease groups in the presence of recommendation and vaccination is shown. There was no statistically significant difference between vaccination rate and disease groups ( $p^{C V D}=1.00 ; p^{D M}=0.68$; $\left.p^{A s t h m a / C O P D}=0.18 ; p^{\prime m m u n o s u p p r e s s i o n}=0.26\right)$. At the same time, there was no significant difference in presence of recommendation between participants with a CVD, DM, astma/COPD or immunsupression and those without any disease $(p=0.12)$, too ( $p^{C V D}=0.22 ; p^{D M}=0.75 ; p^{A s t h m a / ~}$ $\mathrm{COPD}=0.30 ; p^{\text {Immunosuppression }=0.28 \text { ) }}$

Regarding knowledge about the seasonal influenza vaccine, more than half of the participants ( $n=206,52.7 \%$ ) knew how often (yearly) they should receive the vaccine, 213 (54.5\%) participants knew when (month) the vaccine was administered, and 204 of all (52.2\%) knew about free influenza vaccination for those aged $\geq 65$ years or having medical conditions which increase the risk of influenza disease complications.

Two hundred and fifty-nine (66.2\%) patients knew that influenza vaccination was recommended for all persons aged 6 months and over. Eleven point eight percent thought that only children might be vaccinated for influenza. The participants reported that the influenza vaccine should be given to older adults (13.8\%), patients with chronic diseases (5.4\%), and tourists (1.3\%) who will travel (pilgrimage, umrah, etc.). One hundred and eighty

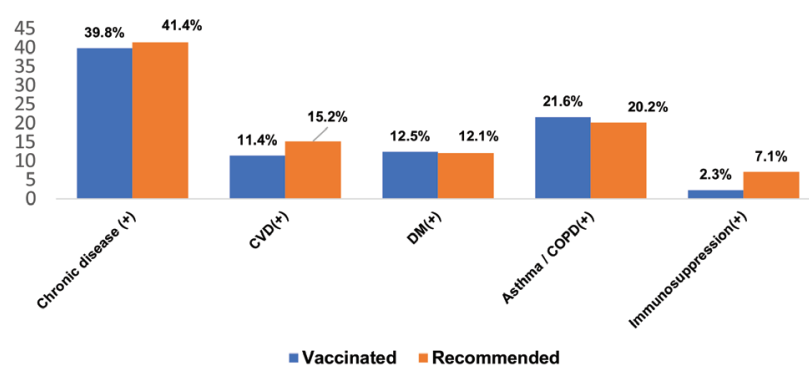

Figure 2. Distribution of the disease percentages in the presence of vaccination and recommendation

CVD: Chronic cardiovascular disease, DM: Diabetes Mellitus, COPD: Chronic obstructive disease five participants were concerned about the risk of seasonal influenza infection (47.3\%), and $318(81.3 \%)$ said they have believed that the influenza vaccine was useful and protective. Sixty-seven percent of participants $(n=262)$ said they intended to receive the vaccine next year.

While the rate of vaccinated adults aged under 65 years who did not experience a flu-like attack last year was $19 \%$, this rate was $33.3 \%$ in the vaccinated elderly, as a good but not significant result $(\mathrm{p}>0.05)$.

Only 15 participants (3.8\%) reported that they experienced side effects from the influenza vaccine. Seventeen point six percent of all had a fear of injection, and 63 patients (16.1\%) were vaccine hesitant, but there was no significant difference in vaccination status $(p>0.05)$.

Figure 3 shows the distributions of variables by the history of a flu-like attack in the past year. $72.6 \%$ $(n=284)$ of patients reported that they had a flu attack in the past year. Seventeen point nine percent of those had been vaccinated. Although there was no anti-viral drug use or prescription, $48.6 \%(n=190)$ of participants used antibiotics for a respiratory tract disease last year, and $64.8 \%$ of those had a history of flu-like illness. There was a significant difference in antibiotic use between flu-like disease $(-)$ and $(+)$ groups $(p<0.001)$. According to the chronic disease types, absence of DM and presence of asthma/COPD in patients with a flulike $(+)$ history in the past year was a significant finding $(p=0.01)$. The number of patients with DM was lower in the flu-like history $(+)$ group (8.5\%) than in the flulike history (-) group (16.8\%). In the comparison of the previous flu-like illness status, the percentage of patients, who worried about getting the flu, believed benefits of influenza vaccine, had a mind to receive the vaccine, and knowledge of influenza vaccination period and vaccination time, was significantly higher in last

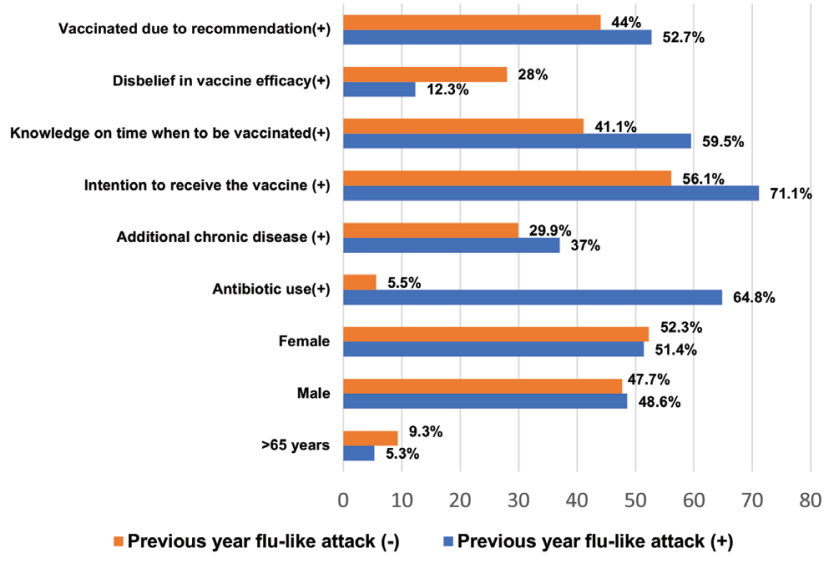

Figure 3. Evaluation of characteristics by the history of a previous year flu-like attack 
year history $(+)$ patients $(p=0.05 ; p<0.001 ; p=0.005$; $p=0.001 ; p=0.001$ ) respectively.

\section{Assessment of Risk Factors by Logistic Regression}

As seen in Table 2, the logistic regression analysis showed that the odds of having vaccination are 5.35 times [ $p<0.001$; Odds ratio (OR): 5.35; 95\% confidence interval (Cl): 2.92-9.78] higher for the presence of recommendations, 5.42 times ( $p=0.01$; OR: 5.42; 95\% $\mathrm{Cl}$ : 1.40-21.03) higher for having the benefit belief, and 4.18 times ( $p=0.001$; OR: $4.18 ; 95 \% \mathrm{Cl}$ : 1.82-9.59) higher for knowing vaccination time. Our model showed that presence of recommendation, information about timing of vaccination, and belief in the benefits of the vaccine are the predictors of favorable vaccination rates, explaining with $82.6 \%$ correctness for model prediction.

\section{Discussion}

This study evaluated the status of influenza vaccination and related factors among patients who applied to a family medicine outpatient clinic for vaccination. Although $81.3 \%$ of the study population reported that vaccination was beneficial and half of the patients positively reacted when their physician recommended the vaccine, both the influenza immunization and the recommendation rates (22.5\%; $25.3 \%$ respectively) were not at desirable levels

\begin{tabular}{|c|c|c|c|c|c|}
\hline \multirow{2}{*}{ Variables } & \multirow{2}{*}{$p$ value } & \multirow{2}{*}{ OR } & \multicolumn{2}{|l|}{$95 \% \mathrm{Cl}$} & \multirow{2}{*}{$\begin{array}{l}\text { Percentage } \\
\text { correct (\%) }\end{array}$} \\
\hline & & & Lower & Upper & \\
\hline $\begin{array}{l}\text { Presence of } \\
\text { recommendation }\end{array}$ & $<0.001 *$ & 5.35 & 2.92 & 9.78 & \multirow{9}{*}{$82.6 \%$} \\
\hline $\begin{array}{l}\text { Employment } \\
\text { status (working) }\end{array}$ & 0.07 & 1.81 & 0.96 & 3.43 & \\
\hline $\begin{array}{l}\text { Knowledge on } \\
\text { free payment }(+)\end{array}$ & 0.34 & 1.35 & 0.73 & 2.50 & \\
\hline $\begin{array}{l}\text { Anxiety for } \\
\text { catching flu (+) }\end{array}$ & 0.65 & 1.15 & 0.63 & 2.14 & \\
\hline $\begin{array}{l}\text { Belief in the } \\
\text { benefit of } \\
\text { vaccination (+) }\end{array}$ & $0.01 *$ & 5.42 & 1.40 & 21.03 & \\
\hline $\begin{array}{l}\text { Intention to } \\
\text { receive the } \\
\text { vaccine (+) }\end{array}$ & 0.42 & 1.38 & 0.63 & 3.04 & \\
\hline $\begin{array}{l}\text { Knowledge } \\
\text { about "what } \\
\text { time..." (+) }\end{array}$ & $0.001 *$ & 4.18 & 1.82 & 9.59 & \\
\hline $\begin{array}{l}\text { Knowledge } \\
\text { about "how } \\
\text { often..." (+) }\end{array}$ & 0.29 & 1.46 & 0.72 & 2.97 & \\
\hline $\begin{array}{l}\text { Knowledge } \\
\text { about "where... } \\
\text { " (+) }\end{array}$ & 0.20 & 0.57 & 0.24 & 1.35 & \\
\hline
\end{tabular}

regardless of the difference in demographic characteristics; age, gender, marital status, and educational background and presence of any chronic disease. Considering that the target for influenza vaccination coverage in European countries is $75 \%$, the result in our study is so far behind the target.

Vaccination coverage rates in adult populations remain below the targets, and outbreaks of vaccine-preventable diseases continue to occur even in countries with wellestablished vaccination programs (8). Vaccination must go on all the time, not only in childhood. According to the latest data in Europe, the prevalence of vaccinepreventable diseases for influenza was $44.7 \%$ for older people and $45.6 \%$ for younger adults with specific risk factors (9). In a study including 1401 people in a primary care center, the rate of last season flu vaccination was $11.7 \%$, and the rate of patients who had no information on the influenza vaccine was $62.2 \%$ (10). In our research, half of our patients had adequate information about influenza vaccination, and $66.2 \%$ of our participants knew that vaccination should be given to everybody.

In another study of patients aged 65 years and over, the influenza immunization rate was $28.1 \%$, and the majority of those with a chronic disease and continuous medication use received the vaccine (11). In our study, the elderly immunization rate was $36 \%$, but the difference between vaccinated younger and older adults was not statistically significant, although there was a significant difference in the presence of recommendation. At the same time, vaccinated adults aged $\geq 65$ years had lesser flu-attacks than those aged $<65$ years. It indicates that physicians must continue to recommend the influenza vaccine on visits.

Based on the published prevalence rates, it has been reported that there were approximately 27 to 33 million people and 428,000 health care providers at the risk for influenza infections (12). It has been shown that influenza vaccination coverage rate in 2006 was $5.9 \%$ in adults aged $\geq 65$ years, $9.1 \%$ in those with DM, and $14.9 \%$ in patients with COPD, but another study performed in 2018 showed that influenza vaccination rate was $8.2 \%$ among older adults (12-14). In their cross-sectional study including 350 subjects performed in 2019, Guclu et al. (15) found that $20 \%$ of the study population were vaccinated with the influenza vaccine. In a study including 100 patients with the diagnosis of COPD, the influenza vaccination rate was found to be $40 \%$ (16). In another article, the influenza vaccination rate was $39.9 \%$, and the participants with chronic pulmonary, heart and kidney disease had more tendency to be vaccinated (17). A casecontrol study investigating the effectiveness of influenza vaccine in people with asthma in Scotland over six seasons 
found that influenza vaccine uptake had the potential to reduce influenza-triggered asthma attacks substantially. Vaccination was associated with an overall $55.0 \%$ risk reduction (18). In our study, there was no difference between chronic disease types for vaccination rates, and the most common disease risk group was asthma/COPD. In line with the literature, $29.7 \%$ of patients with chronic lung disease and $26.2 \%$ of patients with diabetes had an influenza immunization.

When we had a look at the flu attack rates and vaccination presence, a comparative study in the elderly from the Netherlands indicated that $18.1 \%$ of vaccinated participants and $7.6 \%$ of unvaccinated (homeopathy use and nothing use) participants had an influenza-like illness (19). In our study, $72.6 \%$ of patients reported that they had a flu-like attack in the past year, and $17.9 \%$ of those who had flu-like illnesses had been vaccinated. The number of patients with diabetes was lower in the vaccinated flu-like history (+) group than in the (-) group. It might be a result of the efficacy of vaccination, although it was not statistically significant. There was no difference in the effectiveness of vaccination between patients with other type of diseases.

Sixty-seven percent of participants who were recommended vaccines before had the intention to receive the vaccine next season. In a study investigating influenza vaccine intention behavior in patients recovering from a medically attended acute respiratory infection, it was found that $37 \%$ of 837 unvaccinated participants intended to be vaccinated the next season. The authors concluded that the best time to offer influenza vaccine in the next season was a medical visit at the time of an acute respiratory illness, especially one in which the provider suspects influenza, (20). In our study, we obtained a higher vaccine intention rate $(71.1 \%)$ among patients with a history of flu-like illness (including acute respiratory infection) than in those with a negative history (56.1\%).

This study showed that the rate of side effects associated with the previous vaccine in all life was only $3.8 \%$ of all. In a study including 300 individuals visiting family medicine centers in Saudi Arabia, 7.7\% of subjects reported having experienced side-effects from the influenza vaccine (21). We observed that side-effect experience, fears about sideeffect, injection anxiety, and vaccine hesitancy were not a statistically significant barrier to vaccination acceptance in our study sample. It was an unexpected result, while the last socio-cultural trend was growing vaccine hesitancy.

Even doctors can be vaccine-hesitant. In a study conducted in 2014, 14\% of French general practitioners were found to have doubts regarding the utility and/or safety of various vaccines (e.g., vaccines against flu and against hepatitis $B$, and those containing aluminum), and
$20 \%$ considered that children were vaccinated against too many diseases. Across the world, the development of the Internet has given antivaccine activists new tools to organize and reach wider audiences $(22,23)$. Fortunately, internet was the least common source of information about vaccination in our study population $(1.5 \%)$, and doctors were the most powerful source of information (89\%). Another result that emerged in the study was that since the majority of recommendations come from physicians, a vaccine-hesitant doctor may increase vaccine hesitancy. So, mandatory vaccination of healthcare professionals would be a part of government health policy in the future.

In a study from Saudi Arabia, it was reported that barriers to vaccination included a desire to avoid medication, the fact that vaccination was not obligatory, concerns about the side-effects of the vaccine, the belief that one was at low risk of acquiring influenza, and the idea that influenza was a simple disease with no need for prevention (21). In England, despite previous campaigns and the latest flu plan initiative by the Department of Health and Social Care, Public Health England, and NHS England, which is designed to increase flu vaccine uptake among frontline health professionals, only $61 \%$ of healthcare staff in England have received the flu jab this flu season and the Government is considering making the vaccination mandatory (24). Immune healthcare workers would protect themselves and act as a barrier against the spread of infections and maintain healthcare delivery during outbreaks, but their vaccine uptake rates have often been low. In order to achieve adequate immunization rates in healthcare workers, mandatory vaccination policies are occasionally implemented by healthcare authorities, but such policies have raised considerable controversy (25). While the level of influenza vaccination is not satisfactory even among healthcare workers, how can vaccination rates increase in the normal population without implementation of mandatory flu vaccination?

Physician's recommendation has been reported to have a positive effect on vaccination rate (73\%) (26). As we observed in our study, the power of recommendation on vaccine uptake was 5.35 times higher in recommendation $(+)$ group than that of the (-) group.

The primary physician who can give information about the benefits of the vaccination and the vaccine time-period information is a family physician. Health policies about primary care centers and family medicine will be beneficial for both vaccination and other disease prevention and protection strategies. Mandatory vaccination is controversial, but the strength of the recommendation is clear. 


\section{Study Limitations}

Firstly, short and inadequate communication between doctors and patients due to time constraints and performance anxiety might have effects on vaccine recommendations in clinical practice. Secondly, faceto-face surveys may cause a bias on a patient-doctor interview that may cause psychological pressure for the ideal response rather than personal response. Thirdly, we asked patients flu attack history with describing symptoms of acute respiratory infection or flu-like illness but could not check with laboratory tests for influenza. The last limitation was the vaccine name. It was difficult to explain that the influenza vaccine means the flu vaccine as widespread informal use.

\section{Conclusion}

This study indicated that half of the patients recommended by a health professional had received the influenza vaccine. As a result, if we can combine a doctor's recommendation with a patient belief of the vaccine's benefit and information about the timing of vaccination (month), we can increase the rates of disease prevention and protection by successful vaccination. The findings of this cross-sectional study can be used to improve influenza vaccination strategies on a national basis.

\section{Authorship Contributions}

Concept: M.M.B., O.B. Design: M.M.B., O.B. Data Collection or Processing: M.M.B., O.B., E.T., S.G.D., H.K.A., R.A. Analysis or Interpretation: M.M.B., O.B. Literature Search: M.M.B., O.B., E.T., S.G.D., H.K.A., R.A. Writing: M.M.B., O.B.

Conflict of Interest: No conflict of interest was declared by the authors.

Financial Disclosure: The authors declared that this study received no financial support.

\section{References}

1. Potter CW. A history of influenza. Journal of applied microbiology 2001;91:572-9.

2. Blasi F, Aliberti S, Mantero M, et al. Compliance with anti-H1N1 vaccine among healthcare workers and general population. Clinical Microbiology and Infection 2012;18:37-41.

3. Tokuc B. Which Threats to Global Health Pose a Problem for Turkey's Health? Balkan medical journal 2019;36:152.

4. Grohskopf LA, Alyanak E, Broder KR, et al. Prevention and control of seasonal influenza with vaccines: recommendations of the Advisory Committee on Immunization Practices-United States, 2019-20 influenza season. MMWR Recommendations and Reports 2019;68:1.

5. Türkiye Enfeksiyon Hastalıkları Ve Klinik Mikrobioloji Uzmanlık Derneği Erişkin Bağışıklama Rehberi Çalışma Grubu (EKMUD)
- Erişkin Bağışıklama Rehberi-2019. Vol 2019. https://www. ekmud.org.tr/haber/264-turkiye-ekmud-eriskin-bagisiklamarehberi

6. McLaughlin JM, McGinnis JJ, Tan L, et al. Estimated human and economic burden of four major adult vaccine-preventable diseases in the United States, 2013. The journal of primary prevention 2015;36:259-73.

7. Ozawa S, Portnoy A, Getaneh $H$, et al. Modeling the economic burden of adult vaccine-preventable diseases in the United States. Health Affairs 2016;35:2124-32.

8. Ozisik L, Tanriover MD, Rigby S, et al. ADVICE for a healthier life: Adult Vaccination Campaign in Europe. European journal of internal medicine 2016;33:14-20.

9. Prevention ECfD, Control. Seasonal influenza vaccination and antiviral use in Europe-Overview of vaccination recommendations and coverage rates in the EU Member States for the 2013-14 and 2014-15 influenza seasons. Stockholm: ECDC 2016.

10. Aksakal FNB, Koçak C, Dikmen AU, et al. Ankara'da Aile Sağlığı Merkezlerine Başvuran 18 Yaş Üstü Kişilerin Erişkin Aşılamasına Ilişkin Bilgi, Tutum ve Davranışlarının Araştırılması. FLORA 2018;23:124-34.

11. Bal H, Börekçi G. Mersin ilindeki bir aile sağlığı merkezine kayıtlı altmış beş yaş ve üstü bireylerin erişkin aşılama durumları ve etkileyen faktörler. İstanbul Med J 2016;17:121-30.

12. Ciblak MA, Platformu G. Influenza vaccination in Turkey: prevalence of risk groups, current vaccination status, factors influencing vaccine uptake and steps taken to increase vaccination rate. Vaccine 2013;31:518-23.

13. Illhan B, Bakkaloğlu OK. Vaccination rates in geriatric outpatient clinic in gaziantep Dr. Ersin Arslan training and research hospital. Haseki Tıp Bülteni 2019;57:75.

14. Biberoğlu K, Biberoğlu S, Özbakkaloğlu M. Haydi büyükler aşıya. Actual Med 2006;14:18-26.

15. Guclu OA, Demirci H, Ocakoglu G, et al. Relationship of pneumococcal and influenza vaccination frequency with health literacy in the rural population in Turkey. Vaccine 2019;37:6617-23.

16. Erer OF, Karadeniz G, Gazibaba D, et al. Kronik Obstrüktif Akciğer Hastalığında Aşılanma; Gerçekten Yaptırtıyor muyuz? İzmir Göğüs Hastanesi Dergisi 2013;27:31-40.

17. Coşkun FO, Sargın M. Aile hekimliği polikliniğine başvuran 65 yaş ve üstü kişilerde aşılanma sıklığı ve farkındalığı. Ankara Medical Journal 2018;18:1-13.

18. Vasileiou E, Sheikh A, Butler CC, et al. Seasonal influenza vaccine effectiveness in people with asthma: a national testnegative design case-control study. Clinical Infectious Diseases 2019.

19. Hasselaar G, van Nijnatten W, Golden I. A Pilot Study into the Comparative Effectiveness and Safety in the Elderly of a Homeopathic Flu Prophylaxis and the Regular Flu Vaccination in the Netherlands. Homœopathic Links 2016;29:120-6. 
20. Nowalk MP, Balasubramani G, Zimmerman RK, et al. Influenza Vaccine Intention After a Medically Attended Acute Respiratory Infection. Health promotion practice 2019;20:539-52.

21. Sagor KH, AlAteeq MA. Beliefs, attitudes and barriers associated with the uptake of the seasonal influenza vaccine among patients visiting primary healthcare clinics. Saudi medical journal 2018;39:690.

22. Ward JK, Peretti-Watel P, Bocquier A, et al. Vaccine hesitancy and coercion: all eyes on France. Nature immunology 2019;20:1257-9.

23. Verger $\mathrm{P}$, Collange F, Fressard $L$, et al. Prevalence and correlates of vaccine hesitancy among general practitioners: a cross- sectional telephone survey in France, April to July 2014. Eurosurveillance 2016;21.

24. Glasper A. Should influenza vaccination be mandatory for healthcare staff? British Journal of Nursing 2020;29:120-1.

25. Galanakis E, Jansen A, Lopalco PL, et al. Ethics of mandatory vaccination for healthcare workers. Eurosurveillance 2013;18:20627.

26. Egici MT, Taş BG, Özkarafakılı MA, et al. Evaluation of Factors Affecting Adult Immunization. The Medical Journal Of Haydarpaşa Numune Training and Research Hospital 2018;58:128-32. 